\title{
Multi-criteria Decision Analysis Approach to Mine Closure Planning - A Case Study
}

\author{
Peter Arroja Eshun ${ }^{1}$, Eli Andrews Davies-Ocloo ${ }^{2} \&$ Newton Amegbey ${ }^{1}$ \\ ${ }^{1}$ Mining Engineering Department, University of Mines and Technology, Tarkwa, Ghana \\ ${ }^{2}$ Asanko Gold Ghana Limited, Ghana \\ Correspondence: Peter Arroja Eshun, Mining Engineering Department, University of Mines and Technology, P. O. \\ Box 237, Tarkwa, Ghana. Tel: 233-244-658-670 E-mail: paeshun@umat.edu.gh
}

Received: April 5, 2018

Accepted: May 2, 2018

Online Published: May 11, 2018

doi:10.5539/enrr.v8n2p100

URL: https://doi.org/10.5539/enrr.v8n2p100

\begin{abstract}
As mining and environmental regulations continue to get tighter on mine closure and reclamation, the choice of an optimal post mining land use becomes critical if mining companies are to continue enjoying the peaceful co-existence they have with their local communities. In this study, possible mine closure alternatives have been identified as suitable for the Salman south pit of Adamus Resources Limited in the Western Region of Ghana. These alternatives are: arable farm land; timber production; shrubs and native forestation; aquaculture; water reservoir; land fill; and recreational site (park). Effective consideration has been given to the identified technical, environmental, economic, and social criteria to assist in the determination of the optimal choice among the identified suitable closure alternatives. Using the Preference Ranking Organisation Method for Enrichment Evaluation (PROMETHEE) technique of multi-criteria decision analysis, it was observed from the results that arable farmland was the most preferred choice followed very closely by timber production. Others like aquaculture, recreational site (park), shrubs and native forestation, water reservoir, and landfill followed in a decreasing order. In order to satisfy all the various stakeholders in the mine closure process, it is therefore recommended that arable farmland and/or timber production be adopted as the optimal post mining land use for the study area.
\end{abstract}

Keywords: Mine closure; multi-criteria decision analysis; post mining land use; promethee.

\section{Introduction}

Over the past decade, many national mineral regulators have continued to tighten regulations and guidelines on mine closure planning to mitigate existing land degradation problems and prevent future mining legacy liabilities. Environmental regulators are also enacting stricter policies to ensure that these environmental problems are minimised. With the recent global attention to the environmental impact of mining activities, mining companies cannot afford to approach the mine closure planning process with the same attitude as decades ago. This is because the irreversibly destructive nature of mining demands that mining communities be provided with a viable development plan to enhance their livelihood and economic prosperity after the mines have closed and tenement relinquished.

The Salman south pit of Adamus Resources Limited (ARL) was one of the first pits to be mined on the project. It has over the years produced about $4072000 \mathrm{t}$ of ore with an average grade of $1.94 \mathrm{~g} / \mathrm{t}$ containing 253981 ounces of gold. Having depleted the Salman south pit reserve, the next activity is to prepare the pit for closure. To allow ARL to continue growing and developing its social license to operate, the choice of an optimal post mining land use is critical. Typically, choosing an optimal post mining land use is characterised by conflicting development objectives and constraints, large datasets, time consuming analysis and uncertainties. Effective consideration has to be given to regulatory, safety, environmental, social and financial sustainability during the decision-making process. The different stakeholders have different interests and values that interact with each other making the decision-making process much more complicated. The complex nature of choosing an optimal post mining land use that satisfies all the stakeholders involved calls for a multi-criteria approach to making this decision. This paper seeks to apply the Preference Ranking Organisation Method for Enrichment Evaluation (PROMETHEE) to decide on the optimal choice of post mining land use for the Salman south pit. 


\subsection{Brief Information about Study Area}

\subsubsection{History and Ownership}

The area occupied by Adamus Resources Limited (ARL) has had no previous formal mining history with the exception of the Akanko area that forms part of the Salman-Akanko pit chain to the north. Non-mechanised mining occurred in the area in the early 1890's and again in the 1930's. The area has since had no record of any form of formal mining but illegal artisanal mining is being practised in the Anwia area. A number of companies including the Ghana National Manganese Corporation, Ghana Exploration Limited and later on, BHP Billiton, Resolute, Semafo, Samax and Ashanti Goldfields have all undertaken exploration studies within the area. Adamus Resources Limited (ARL), a subsidiary of Endeavour Mining Corporation currently holds the license to the Nzema Gold Project. ARL acquired the Salman area in 2002, the Akanko (Salman North) in 2003 and the Anwia area in 2004 (Johnson, de Klerk, Yeo, \& Roux, 2013).

\subsubsection{Location and Accessibility}

The project is located in the south-western part of Ghana and it is within the Nzema East District with Nkroful as the District capital and Jomoro as the traditional area. It is approximately $280 \mathrm{~km}$ west of Ghana's capital city, Accra. The Project is accessed from Accra via a sealed road to Teleku Bokazo via Takoradi, and then by $10 \mathrm{~km}$ of all-weather road (Johnson, de Klerk, Yeo, \& Roux, 2013). Figure 1 shows the location map of the project area.

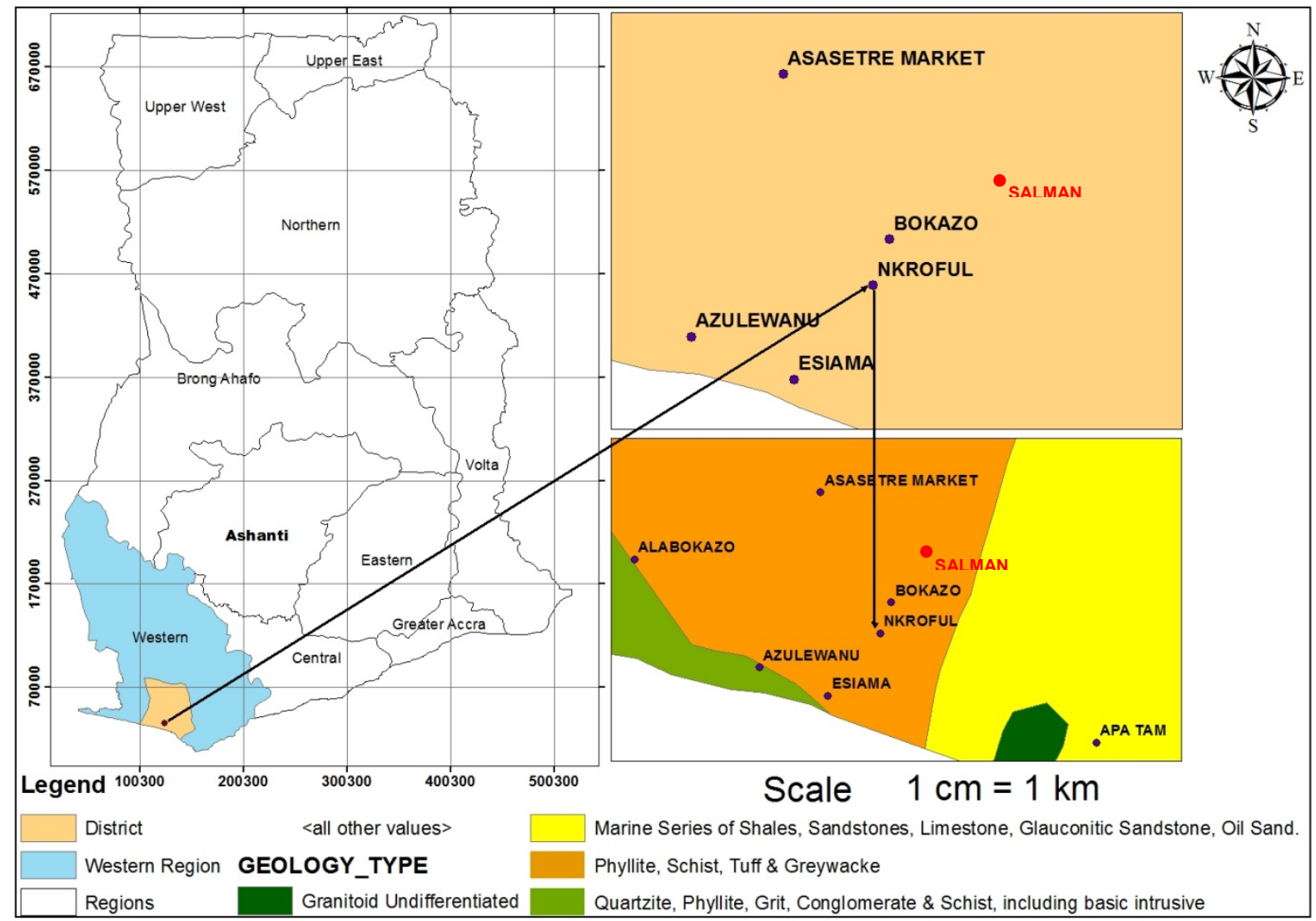

Figure 1. Location Map of Project Area (Source: Authors' Construct)

\subsubsection{Site Description and Layout}

The Project comprises the development of two distinct mining areas, namely the Anwia-Bokazo Mine Area and the Salman-Akanko Mine Area which cover a total area of $450 \mathrm{~km}^{2}$. The mine footprint is however confined to an area totalling approximately $4.0 \mathrm{~km}^{2}$ (400 ha). The Salman-Akanko Mining area comprises a series of north-south trending pits (Johnson, de Klerk, Yeo, \& Roux, 2013). Other mine related infrastructure include 
associated waste dumps, treatment plant, Tailings Storage Facility (TSF), mine services area and administrative block. The Salman concession and project infrastructure are illustrated in Figure 2.

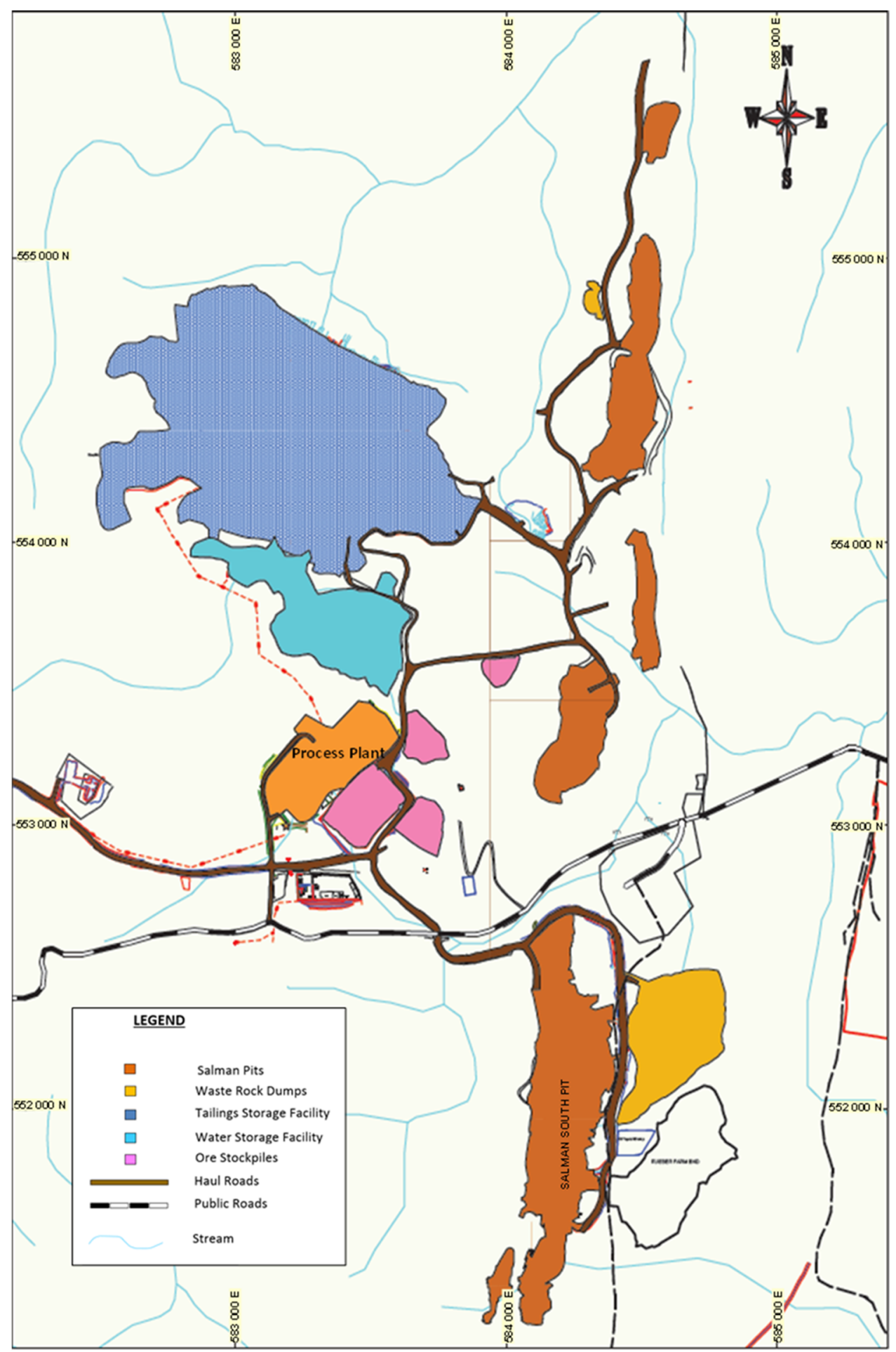

Figure 2. Site Plan of Salman Concession and Project Infrastructure (Source: Authors' Construct) 


\subsection{Mine Closure Planning}

\subsubsection{The Closure Planning Process}

Mining operations inevitably cause changes in the surrounding environment, the extent of which depends upon the nature of the ore, mining and treatment methods and the size, geometry and location of the deposit (Heikkinen et al., 2008).

Mine closure refers to the final stages of mining activity, after production and processing have permanently ceased and any subsequent activities that are directly related to shutdown of the mine (site rehabilitation and on-going monitoring) (Heikkinen et al., 2008).

The intent of mine closure is to return the land to as close as is reasonably possible to its pre-disturbance condition, suitable for use by traditional owners and as habitat for flora and fauna (Department for Communities and Local Government, 2009). To do this, a process must be established to guide all decisions and actions during a mine's life such that: future public health and safety are not compromised; environmental resources are not subject to physical and chemical deterioration; the post-mining use of the site is beneficial and sustainable in the long term; any adverse socio-economic impacts are minimised; and opportunity is taken to maximise socio-economic benefits (Mougeot, 2002).

In a perfect world, mines only close when their mineral resources are exhausted and a mine closure plan is put in place and progressively implemented. In the real world, however, mines extract reserves not resources. Reasons for mine closure other than exhaustion of reserves include (Working Group, 2006):

1) Economic - such as low commodity prices or high costs may lead a company into voluntary administration or receivership;

2) Geological - such as an unanticipated decrease in grade or size of the ore body;

3) Technical - such as adverse geotechnical conditions or mechanical/equipment failure;

4) Regulatory - due to safety or environmental breaches;

5) Policy changes - which occur from time-to-time, particularly when governments change;

6) Social or community pressures; particularly from non-government organisations;

7) Closure of downstream industry or markets; and

8) Flooding or water inrush.

Planning for closure is about how to design a mine operation in order to facilitate closure. The closure planning process (as in Figure 3) begins with planning during the project feasibility assessment phase and concludes with the surrender of tenure. Thus, the earliest possible time to plan for closure is at exploration, although the exploration phase may not necessarily result in an operating mine.

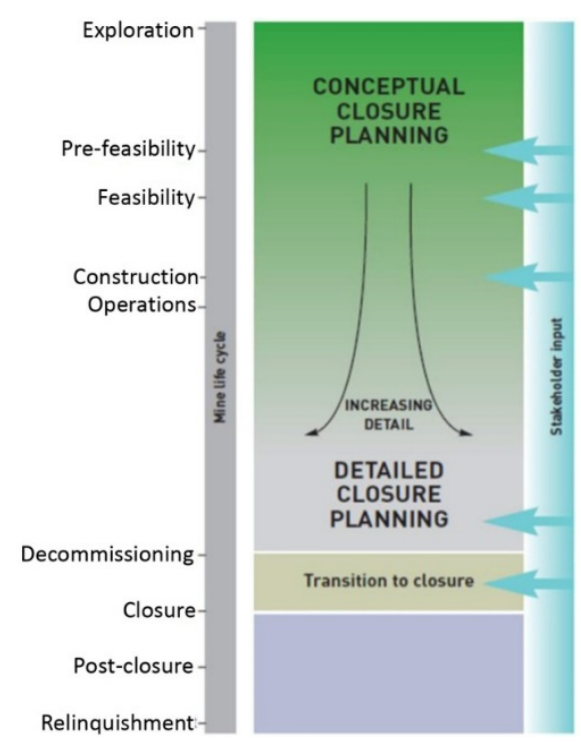

Figure 3. Mine Closure Planning Process (Source: Starke, 2008) 
From Figure 3, initially, a conceptual closure plan is developed and this is used during exploration, pre-feasibility, feasibility/design and construction to guide the direction of activities. Its active life may be three to five years and it spells out the target closure outcomes and goals (Queensland Mining Council (QMC), 2001). A detailed closure plan is then developed and implemented which increases the understanding and detail of specific goals and milestones as well as the actions and outcomes of activities to meet these. This plan is updated and used continuously during operations and it has an active life that could range from 5 to 30 years. There is the potential for expectations of the community and other stakeholders to change during this time. There is also the potential for the mine plan to change, affecting operations as well as the facility life. It is thus likely that the detailed closure plan may evolve in line with changing circumstances (QMC, 2001).

\subsubsection{Alternative Post Mining Land Use}

Very rarely will the post-mining land use be the same as the pre-mining land use, as mining activity would have resulted in some impacts in which such restoration may not be feasible. Although the initial impression in most of the landscape created by mining is one of desolation and dereliction, studies have shown that intensive use has been and is increasingly being made of these areas (Alexander, 1996).

From the perspective of Cao (2007), reclaimed sites have a wide range of potential functions such as: hay-land; recreational areas; wetlands; and swimming pools. Some possible land uses as proposed by Warhurst \& Noronha (2000) to which mined land can be rehabilitated towards are energy plantations for fuel wood, forestry, horticulture and pasture, the use of abandoned pits as water storages to act as buffers of local water supply or as artificial wetlands, and areas for natural conservation or as tourist sites.

Bascetin (2007) identified five potential reclamation alternatives including agriculture, tree planting/forest land, recreational development, large acreage residential development, and new community residential development for a mine site. Soltanmohammadi, Osanloo, Rezaei, \& Aghajani Bazzazi (2008), Bangian, Ataei, Sayadi \& Gholinejad (2011) and Masoumi \& Rashidinejad (2011) proposed agricultural, forestry, recreational, residential, lake or pool, institutional, commercial and industrial as alternative post mining land uses.

\subsubsection{Criteria for Assessing Alternative Post Mining Land Use}

To ensure that the post-mining land use would be viable, a plan for closure has to address the following issues (Warhust \& Noronha, 2000):

1) What are the kinds of environmental and social problems that may continue or arise at the end of the life of the mine?

2) How can these be mitigated or avoided?

3) When should these problems be most effectively addressed from an environmental, social, and economic perspective?

4) Who should be involved in the process of planning for closure?

According to Coppin \& Box (1999), mining will affect the soil-plant-animal system of the region through a number of biological, chemical and physical factors which can be linked with various possible closure alternatives to define the characteristics of the land to make it suitable for a particular end use.

Brodie, Robertson \& Gadsby (1992), Mougeot (2002) and European Commission (2009) touched on physical stability, chemical stability, biological stability, geographic and climatic influence, land use and aesthetics, natural resources, financial consideration, and socio-economic issues as criteria for measuring the closure objective.

Bascetin (2007) in his research looked at cost, natural and cultural factors as criteria for assessing the post mining land use. Soltanmohammadi, Osanloo \& Aghajani Bazzszi (2008) developed a fifty attribute framework for mined land suitability analysis addressing economic, social, technical and mine site factors. Heikkinen et al. (2008) defined safety criteria so as to ensure that risk mitigation procedures are sufficiently robust to cope with all conceivable geological and climatic contingencies.

In general, the decision on the post mining land use will depend not only on social needs, but also on the need to maintain ecological security in the region following mining operations. The net result is a land use that is of more benefit to the local community than the pre-mining land use. This is necessary not only to ensure that the local community is not impoverished because of the loss of the mining activity and the services that it supported, but also to compensate the community for the loss of the resources that in a way were part of its heritage (Warhust \& Noronha, 2000). 


\subsection{Multi-criteria Decision Analysis}

The field of Multi-Criteria Decision Analysis (MCDA) refers to the wide variety of tools and methodologies developed for the purpose of helping a decision maker to select from finite sets of alternatives according to two or more criteria, which are usually conflicting. The main role of MCDA is to deal with the difficulties that human decision-makers have in handling large amounts of complex information in a consistent manner. The major distinguishing aspect of MCDA is the orientation toward decision support (decision aid) rather than simple decision model development. Generally, MCDA approaches are focused on the model development features that are related to the modelling and representations of the decision makers' preferences, values and judgment policy. According to De Montis, De Toro, Droste-Franke, Omamm, \& Stagl (2000), it is used to support decision making in cases where conflicting economic, environmental, societal, technical, and aesthetic objectives are involved. MCDA techniques can be used to identify a single most preferred option, to rank options, to short-list a limited number of options for subsequent detailed appraisal, or simply to distinguish acceptable from unacceptable possibilities.

MCDA is both an approach and a set of techniques, with the goal of providing an overall ordering of options from the most preferred to the least preferred option (Department for Communities and Local Government, 2009). Its purpose is to serve as an aid to thinking and decision making, but not to take the decision. As a set of techniques MCDA provides different ways of disaggregating a complex problem, measuring the extent to which options achieve objectives, weighting the objectives, and reassembling the pieces. Some of the MCDA include:

1) Analytical Hierarchy Process (AHP);

2) Preference Ranking Organisation Method for Enrichment Evaluation (PROMETHEE);

3) Elimination EtChoix Traduisant la REalite (ELECTRE);

4) Technique for Order Preference by Similarity to an Ideal Solution (TOPSIS);

5) Novel Approach to Imprecise Assessment and Decision Environments (NAIADE);

6) Multi-Attribute Utility Theory (MAUT); and

7) Multi-Objective Programming and Goal Programming.

The Analytical Hierarchy Process (AHP) and Preference Ranking Organisation Method for Enrichment Evaluation (PROMETHEE) techniques were employed in this research. According to Hong \& Vogel (1991), in cases or situations, where most of the attributes have a qualitative nature, a non-compensatory approach of MCDA such as TOPSIS, ELECTRE, PROMETHEE, etc. are more useful. These methods don't need the decision maker's subjective judgments. It can be proved as asserted by Joerin, Theriault, \& Musy (2001) that, outranking MCDA techniques such as ELECTRE, PROMETHEE, etc. are well suited for conditions that exist in the Mine Land Suitability Analysis (MLSA) framework. PROMETHEE II method is particularly well-fitted in this research, because it allows a decision to be made from incomparable criteria.

\section{Materials and Methods}

\subsection{Materials}

The data used for the study was collected from the Environmental and Mining Departments of Adamus Resources Ltd. These included the structural geology, bench height, wall stability, regional flora and fauna, hydrology of surface and ground water and current land use in surrounding areas of the Salman south pit and site plan of the mining area. Ground truth surveys were done to validate the site map received. This was done by picking GPS coordinates of road intersection, prominent land marks and survey control points and plotting them against the original data. All geographic datasets were projected coordinates in WGS 1984 UTM Zone 30 North datum. For the qualitative data, validation was done by interviewing the departmental experts on the data received. The validation process helped to attach some degree of accuracy and reliability to the data used for the multi-criteria decision analysis. The Visual PROMETHEE software was used to undertake the multi-criteria analysis.

\subsection{Methods}

The methodology used for selecting the optimal post mining land use is composed of five main stages as follows:

1) Identification of closure alternatives;

2) Identification of relevant criteria for assessing these alternatives; 
3) Evaluation of each criterion against the alternatives to form a decision matrix;

4) Assignment of criteria weights to prioritise the preferences of the decision maker; and

5) Multi-criteria decision analysis using PROMETHEE to assess the closure alternatives against the criteria to determine the optimal choice.

\subsubsection{Identification of Closure Alternatives}

From literature and interviewing the Mine Environmentalists in charge of closure planning, five (5) categories of post mining land use were identified for the Salman south pit. They are agriculture, forestry, lake, pit back-filling and miscellaneous. Of this categorisation, seven (7) definite closure alternatives were identified as suitable for the study area (Table 1).

Table 1. Identified Post Mining Land Use

\begin{tabular}{lll}
\hline Item & Category of Post Mining Land Use & Alternative Post Mining Land Use \\
\hline 1 & Agriculture & Arable farmland \\
2 & Forestry & Timber production \\
& & Shrubs and native forestation \\
3 & Lake & Aquaculture \\
4 & Pit Backfilling & Water reservoir \\
& & Landfill \\
5 & Miscellaneous & Recreational Site (Park) \\
\hline
\end{tabular}

\subsubsection{Identification of Relevant Criteria for Assessing the Alternatives}

Forty (40) influential criteria attributes were outlined for evaluating the identified closure alternatives which were grouped into four main categories (technical, environmental, economic and social) (see Table 2). Figure 4 shows the hierarchical framework for defining the optimal post mining land use.

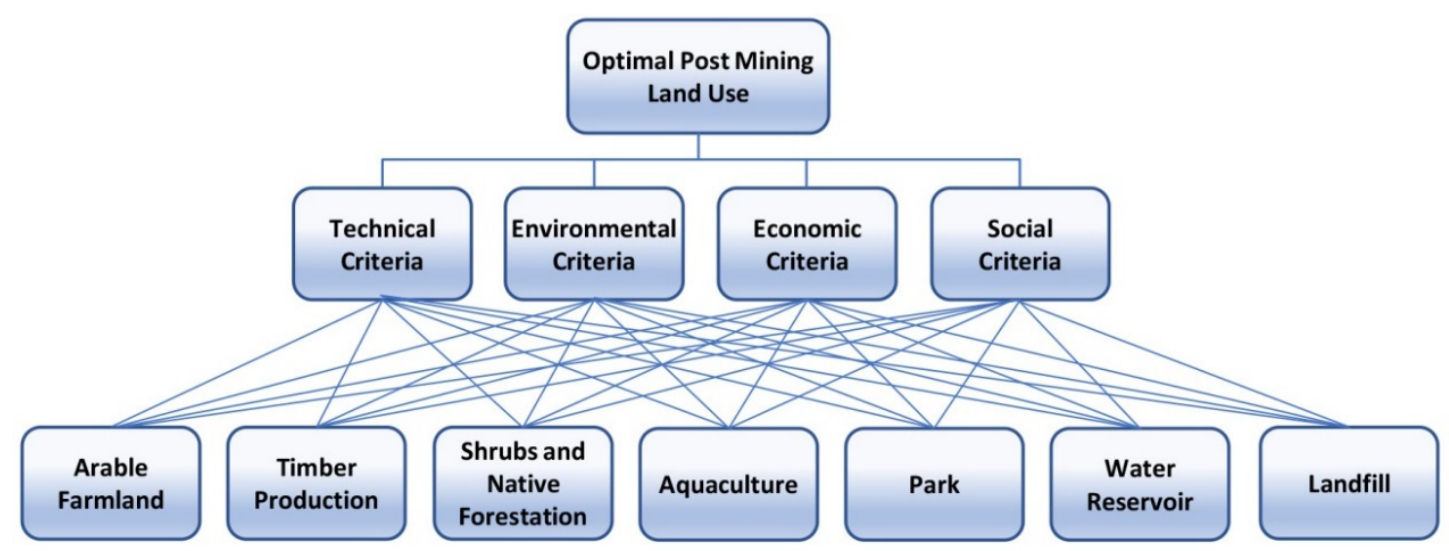

Figure 4. Hierarchical Structure of Post Mining Land Use Framework

Technical criterion: The technical factors are intrinsic and site-specific attributes that affect the decision of optimal post mining land use. They include structural geology, re-use potential of the mine facility, pit geometry, required machines and equipment availability, need for specialist workforce, and overall regional topography. The complete structure of the technical criterion is shown in Figure 5.

Environmental criterion: The environmental factors include soil, ecological acceptability, current land use in surrounding area, climate, and environmental contamination. The schematic structure of the environmental criterion is shown in Figure 6.

Economic criterion: The economic criterion consists of the income and cost of the closure alternatives. This is shown in Figure 7. 
Social criterion: Regional safety condition, positive change in livelihood, cultural, tourism attraction, employment opportunities, legal, and regional potential for implementing the new land use make up the social criterion. Figure 8 shows the structure of the social criterion.

Table 2. Criteria for Assessing Closure Alternatives

\begin{tabular}{|c|c|c|}
\hline \multirow[t]{12}{*}{ TECHNICAL CRITERION } & \multicolumn{2}{|c|}{ Structural geology } \\
\hline & \multicolumn{2}{|c|}{ Re-use potential of mine facility } \\
\hline & \multicolumn{2}{|c|}{ Required machines and equipment availability } \\
\hline & \multicolumn{2}{|c|}{ Need for specialist workforce } \\
\hline & \multicolumn{2}{|c|}{ Overall regional slope/Topography } \\
\hline & \multirow[t]{7}{*}{ Pit Geometry } & Wall stability \\
\hline & & Bench height \\
\hline & & Bench width \\
\hline & & Bench slope \\
\hline & & Pit volume \\
\hline & & Pit area \\
\hline & & Pit depth \\
\hline \multirow[t]{13}{*}{ ENVIRONMENTAL CRITERION } & \multirow[t]{6}{*}{ Soil } & Erosion Rate \\
\hline & & Porosity \\
\hline & & Water Conduction ability \\
\hline & & Salinity rate \\
\hline & & Organic material and nutrient element \\
\hline & & 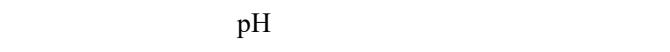 \\
\hline & \multirow[t]{4}{*}{ Climate } & Regional flora and fauna \\
\hline & & Hydrology of surface and groundwater \\
\hline & & Regional average temperature \\
\hline & & Precipitation \\
\hline & \multicolumn{2}{|c|}{ Ecological acceptability } \\
\hline & \multicolumn{2}{|c|}{ Current land use in surrounding area } \\
\hline & \multicolumn{2}{|c|}{ Environmental contaminations } \\
\hline \multirow[t]{5}{*}{ ECONOMIC CRITERION } & \multirow[t]{3}{*}{ Income } & Mining project income \\
\hline & & Increase in income of local community \\
\hline & & Increase in government income \\
\hline & Cost & Operational cost \\
\hline & & Capital cost \\
\hline \multirow[t]{10}{*}{ SOCIAL CRITERION } & \multicolumn{2}{|c|}{ Regional safety condition } \\
\hline & \multicolumn{2}{|c|}{ Positive changes in livelihood quality } \\
\hline & Cultural & Regional social activities \\
\hline & & Regional moral and ethnic customs \\
\hline & & Social and cultural condition of adjacent areas \\
\hline & Tourist attracti & \\
\hline & Employment o & nity \\
\hline & Legal & Statutory Regulations \\
\hline & & Mining Company policy \\
\hline & Regional poter & implementing the new land use \\
\hline
\end{tabular}




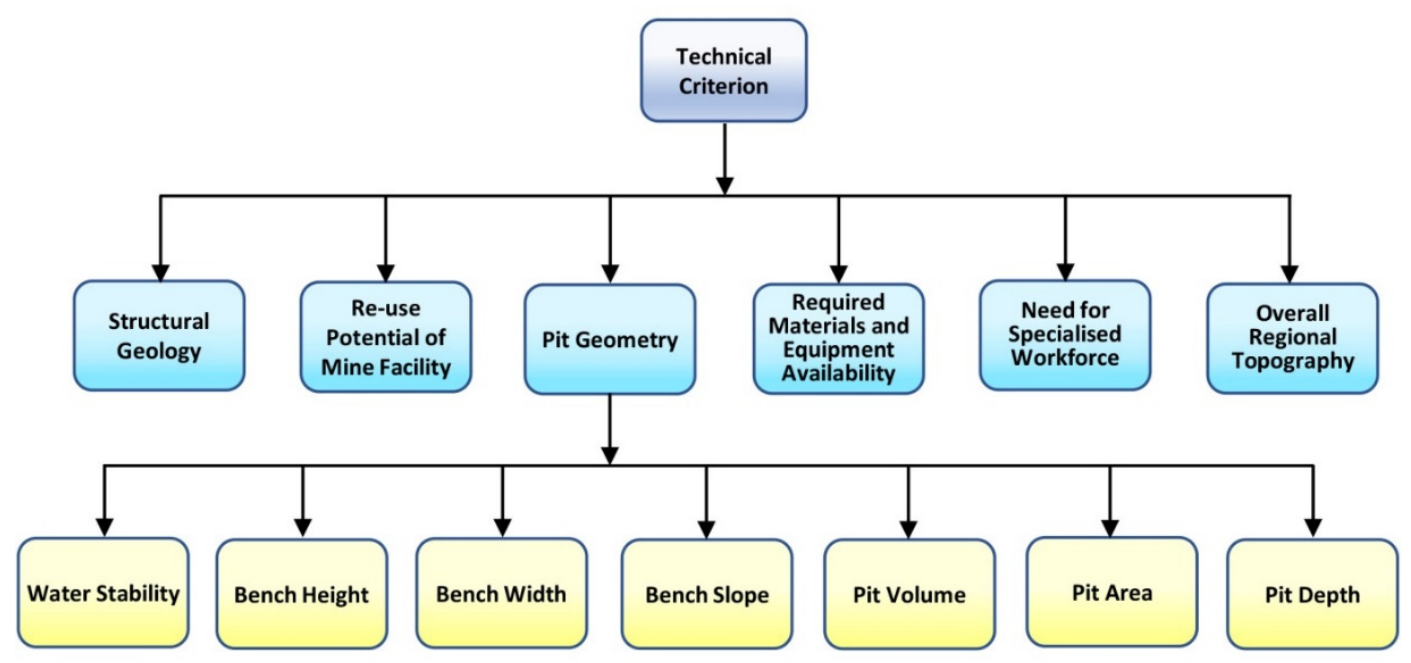

Figure 5. Structure of the Technical Criterion

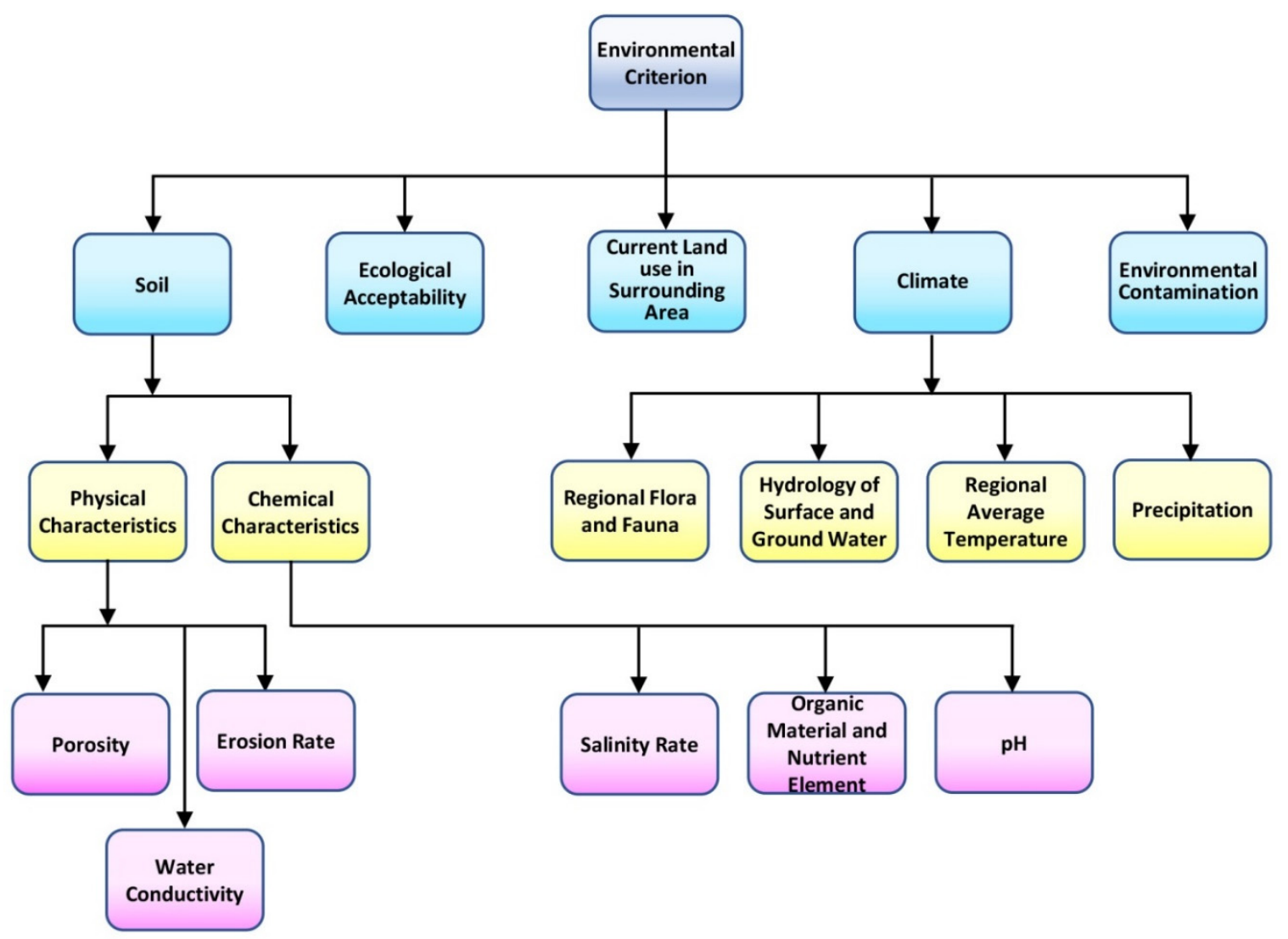

Figure 6. Structure of the Environmental Criterion 


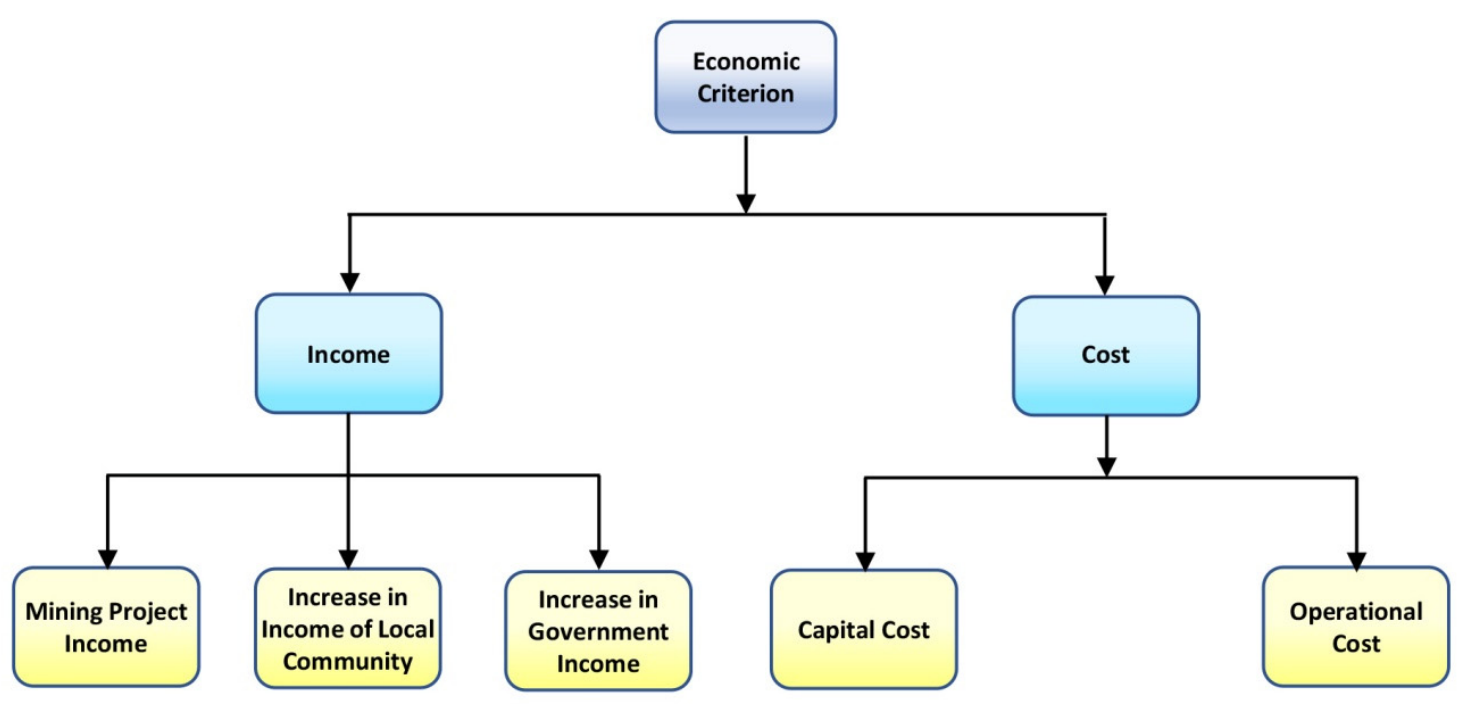

Figure 7. Structure of the economical criterion

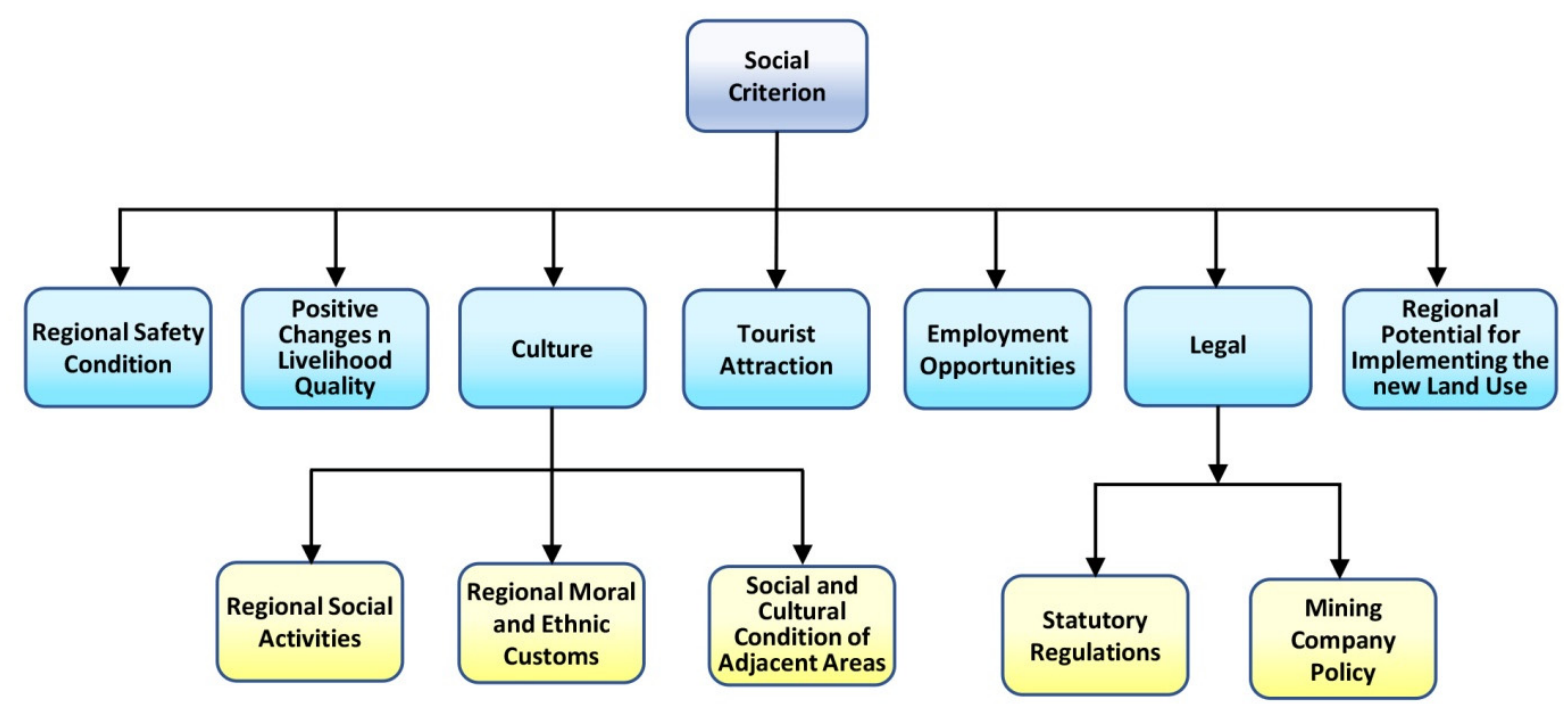

Figure 8. Structure of the Social Criterion

\subsubsection{Evaluation of Criteria against Closure Alternatives}

A group of 5 experts (one each from the Mining, Safety, Geology, Community, and Environment Departments of the mine) were presented with the seven (7) definite closure alternatives and the forty (40) influential criteria attributes for measuring each. They then scored each criterion against the alternatives using a five-point qualitative scale (Very Bad $\{1\}$, Bad $\{2\}$, Average $\{3\}$, Good $\{4\}$ and Very Good $\{5\}$ ) based on their experience and engagement with the communities. For instance, the group had to score the impact of the closure alternatives on the local communities (social criterion) in terms of its positive changes on their quality of livelihood. The results of the scores were then fed into the Visual PROMETHEE software for the processing of the optimal post mining land use.

\subsubsection{Application of Criteria Weights using Analytical Hierarchy Process Technique}

To determine the extent of influence of each criterion on the choice of the optimal closure alternative, the criteria were weighted. To do this, the group of experts scored each criterion on the relative importance of the criterion using a 1 to 9 weighting scale as shown in Table 3. Priorities were then calculated from pairwise comparisons of 
the criterion using the Analytic Hierarchy Process (AHP) with eigen vector method. The pairwise comparison indicates which of the criteria in each pair is more important, and by how many times more on the 1 to 9 scale.

The resulting weights of the criteria are shown in Figure 9. The weights were then passed through the PROMETHEE method so that the optimal post mining land use could be appointed by comparisons of pairwise dominance relationships between the closure alternatives.

Table 3. Weighting Scale for the Analytical Hierarchy Process

\begin{tabular}{lc}
\hline Preferences (Judgments) & Numerical value \\
\hline Extremely preferred & 9 \\
Very strongly preferred & 7 \\
Strongly preferred & 5 \\
Moderately preferred & 3 \\
Equally preferred & 1 \\
Intermediate values & $2,4,6,8$ \\
\hline
\end{tabular}

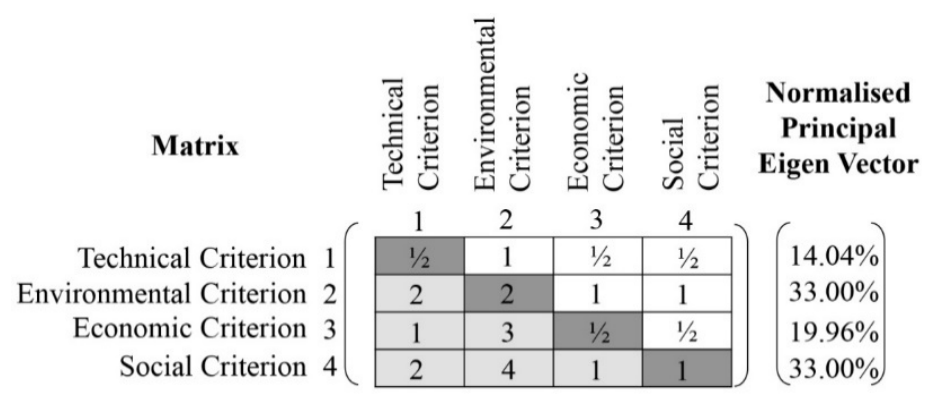

Figure 9. Determined Weights for the Criteria

\subsubsection{Multi Criteria Decision Analysis of Closure Alternatives}

Once the results of the criteria scoring were entered into the Visual PROMETHEE software, each criterion was set to be either minimised or maximised depending on its effect in determining the optimal post mining land use. For instance, all the cost and environmental contamination elements in the criteria were set to minimised while others like employment opportunity, regional safety condition, tourist attraction and positive changes in livelihood quality were set to be maximised. The AHP calculated weights were then allocated to the criteria to reflect the priorities of the decision-maker.

\section{Results and Discussion}

\subsection{PROMETHEE I Ranking of the Alternative Post Mining Land Uses}

The PROMETHEE I partial ranking analysis is based on the computation of Phi+ and Phi- preference flows of the closure alternatives. Figure 10 shows the graphical representation of the PROMETHEE 1 ranking of the alternatives.

Under the PROMETHEE I analysis, Phi+ measures how much an action "A" is preferred to the other $\mathrm{n}-1$ actions. It is a global measurement of the strengths of action " $\mathrm{A}$ ". Phi- on the other hand measures how much the other n-1 actions are preferred to action "A". It is a global measurement of the weaknesses of action " $\mathrm{A}$ ". The PROMETHEE I partial ranking is displayed by drawing a line for each action between its $\mathrm{Phi}+$ score on the left vertical bar and its Phi- score on the right vertical bar. When a line is on top of another it means that the action is preferred to the other. When two lines are crossing each other, it means that the actions are incomparable under PROMETHEE I.

The results of the PROMETHEE I analysis of the closure alternatives (Figure 10) ranked arable farmland (with positive flow Phi+ of 0.1584 and negative flow Phi- values of -0.0780) and timber production (with positive flow Phi+ of 0.2500 and negative flow Phi- values of -0.0919) as the optimal choice. These two alternatives, however, are incomparable as they cross each other. Landfill (with positive flow Phi+ of 0.0858 and negative flow Phi- of 0.506) was the least option of choice under this partial ranking (as it has the lowest positive flow 
Phi+ and the highest negative flow Phi-). Water reservoir, and shrubs and native forestation also show incomparability. Recreational site (Park) and aquaculture are also incomparable under this partial ranking since their ranking cross each other as shown in Figure 10.

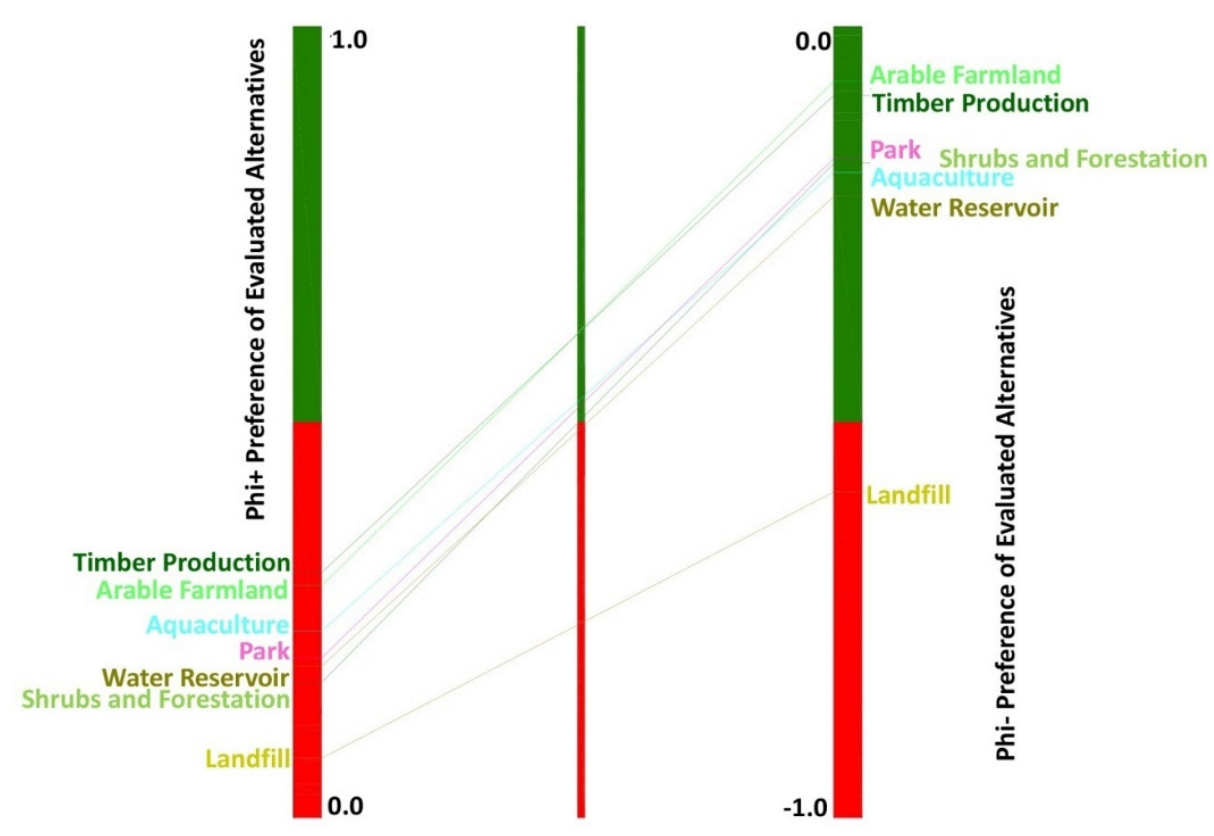

Figure 10. Graphical representations of PROMETHEE I ranking

\subsection{PROMETHEE II Ranking of the Alternative Post Mining Land Use}

The PROMETHEE II complete ranking analysis is based on the net preference flow (Phi) of the alternatives. Table 4 presents the estimates of the net preference flow (Phi) and Figure 11give a graphical presentation. From Figure 11, three groups of closure alternatives are easily visible. Arable farmland and timber production are ranked at the top as the optimal choice. This is followed by aquaculture, recreational site (park), shrubs and native forestation, and water reservoir as the second group of choice. Landfill on the other hand is separated at the bottom.

\subsection{PROMETHEE Diamond Analysis}

The diamond ranking analysis shows a 2-dimensional representation of both PROMETHEE I and II ranking of the closure alternatives. This is shown in Figure 12. It also ranks arable farmlands and timber production ahead of all the other alternatives with landfill ranked the least preferred alternative.

Table 4. Positive, negative and net flows

\begin{tabular}{|c|c|c|c|c|}
\hline Rank & Action & Phi+ & Phi- & Phi \\
\hline 1 & Arable Farmland & 0.2936 & 0.0692 & 0.2244 \\
\hline 2 & Timber Production & 0.3101 & 0.0867 & 0.2234 \\
\hline 3 & Aquaculture & 0.2359 & 0.1836 & 0.0523 \\
\hline 4 & Park & 0.2023 & 0.1664 & 0.0359 \\
\hline 5 & Shrubs and Native Forestation & 0.1714 & 0.1725 & -0.0011 \\
\hline 6 & Water Reservoir & 0.1919 & 0.2144 & -0.0225 \\
\hline 7 & Landfill & 0.0755 & 0.5878 & -0.5123 \\
\hline
\end{tabular}




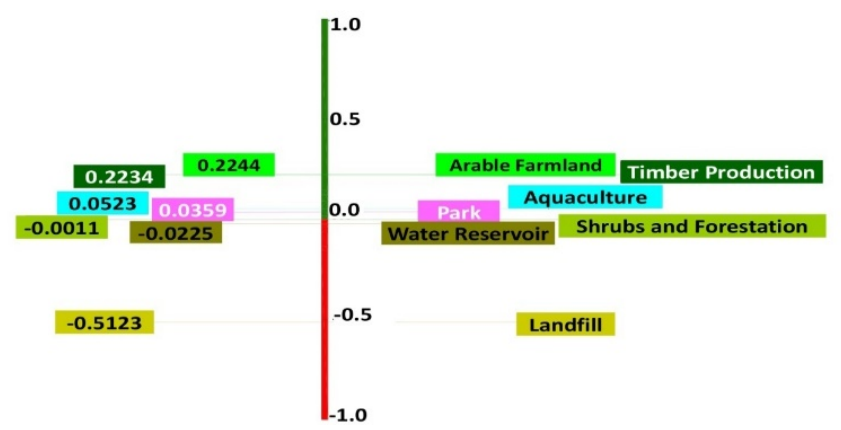

Figure 11. Graphical representation of PROMETHEE II ranking

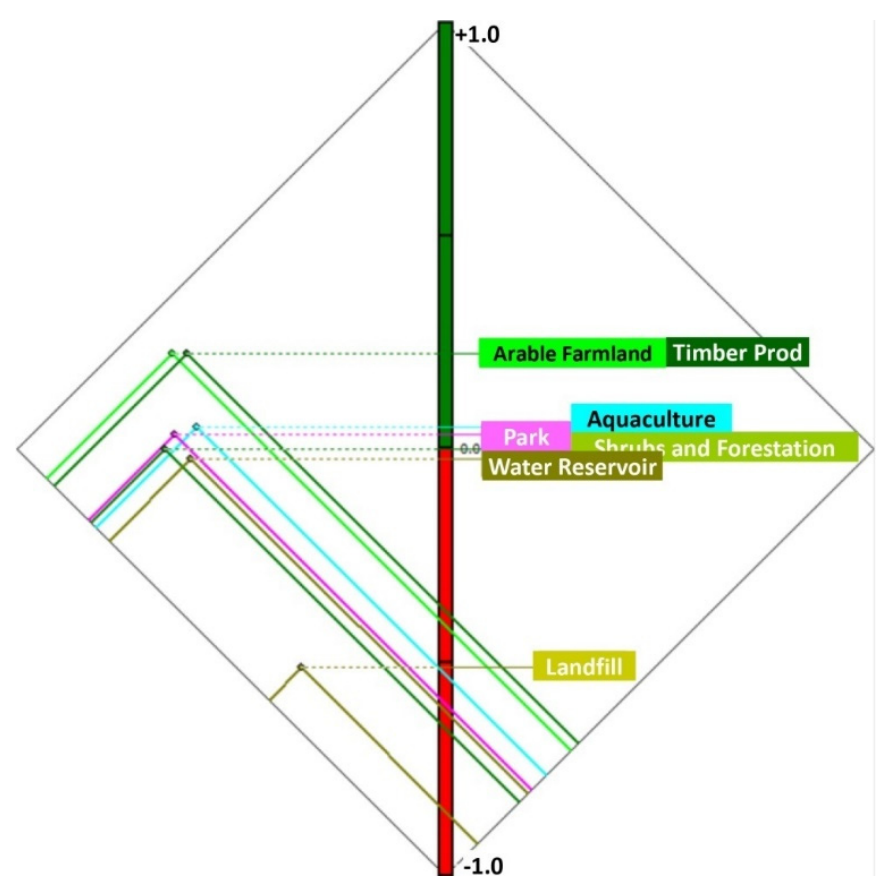

Figure 12. Graphical representation of PROMETHEE diamond analysis

\subsection{Geometrical Analysis for Interactive Assistance (GAIA)}

The Geometrical Analysis for Interactive Assistance (GAIA) plane graphically shows how the alternatives are different or similar to each other, which criteria are conflicting with others and groups of criteria expressing similar preferences. This is shown in Figure 9. On the GAIA plane (Figure 13), each closure alternative is represented by a point. Each criterion is also represented by an axis drawn from the centre of the GAIA plane. Criteria that express similar preferences have axes that are close to each other.

It can be observed from Figure 13 that the environmental and social criteria axes are closer and therefore have similar preference. That is, from the analysis all the alternatives that are environmentally friendly are also more socially acceptable. Technical and economic criteria on the other hand conflicts since their axes points in opposite directions. That is, closure alternatives that favour the technical criteria are not necessarily economical.

Three distinct closure alternative profiles can also be observed from the GAIA plane in Figure 13. The analysis shows that water reservoir, and aquaculture have similar preferences; shrubs and native forestation, timber production, recreational site (park) and arable farmland also express similar preferences since they are clustered together while landfill has a different profile from the others because it stands alone.

\subsection{Unicriterion Net Flows}

From the unicriterion net flows analysis, the contribution of each criterion to the net preference flows of the actions taking into account the weight of the criterion is shown in Figure 14. 
For each closure alternative, a bar is drawn with as many slices as the number of criteria. Each slice corresponds to the contribution of the criterion to the Phi net flow score of the choice of closure alternative. It can be observed that arable farmland and timber production have no negative contribution to the overall score. They therefore have no weaknesses compared to the other alternatives. All other closure alternatives (recreational site (park), aquaculture, shrubs and native forestation, water reservoir and landfill) respond better to some criteria and worse on others as shown in Figure 14. However, recreational site (park) has an average profile with very short criteria bars.

\subsection{Results of the Multi-criteria Net Preferences Flow}

The results of the net preference flows are shown in Figure 15. The figure shows the overall ranking of the optimal post mining land use and the weights used in its determination for the study area.

It can be observed that the order of ranking from the optimal to the least preferred is arable farmland, timber production, aquaculture, recreational site (park), shrubs and native forestation, water reservoir and landfill.

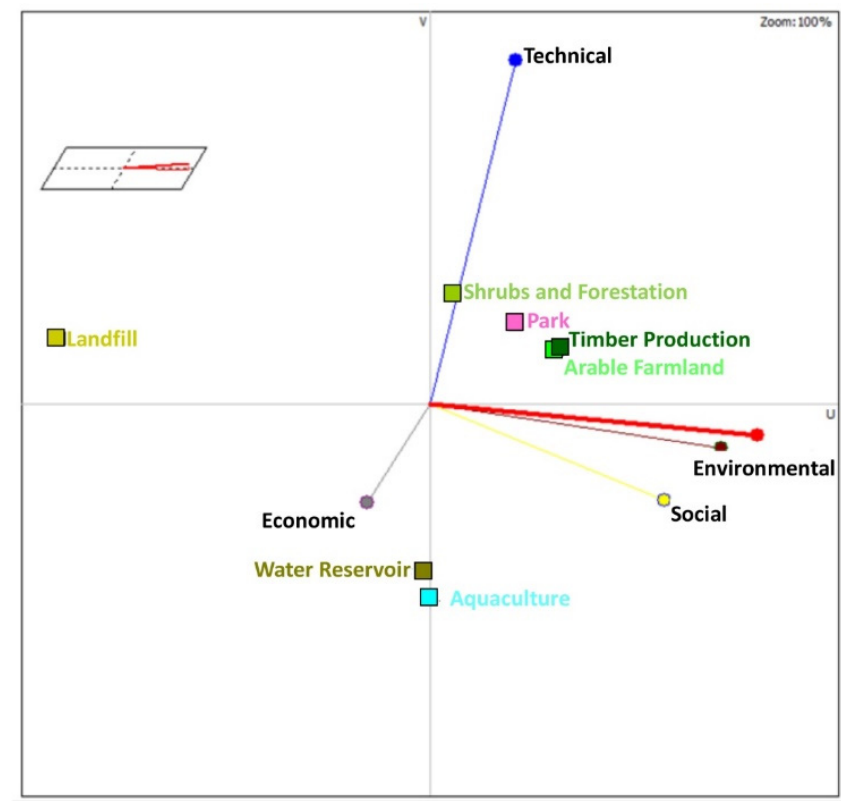

Figure 13. GAIA plane of the closure alternatives and criteria

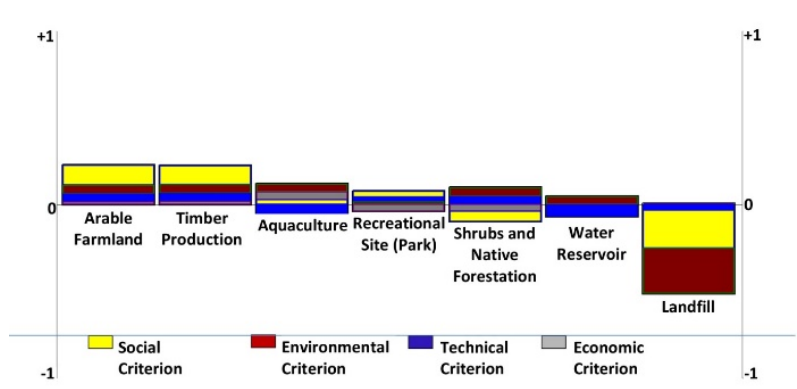

Figure 14. Compositions of unicriterion net flows for the closure alternatives

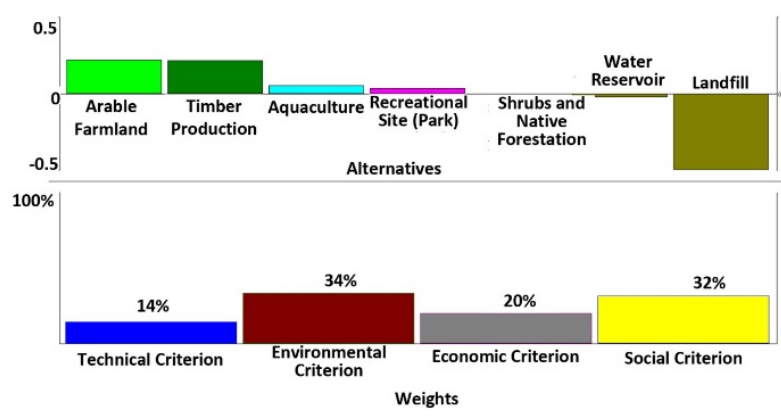

Figure 15. Results of Net Preference Flows

\section{Conclusions and Recommendations}

\subsection{Conclusions}

This study focused on the choice of an optimal post mining land use for the Salman south pit of Adamus Resources Limited. Seven mine closure alternatives have been identified as suitable for the Salman south pit. 
They are arable farm lands, timber production, shrubs and native forestation, aquaculture, water reservoir, land fill and recreational site (park).

Effective consideration has also been given to the identified technical, environmental, economic and social criteria to assist in the determination of the optimal post mining land use among the identified closure alternatives. In all, forty (40) sub-criteria were used to evaluate the identified closure alternatives.

Using the PROMETHEE technique of multi-criteria decision analysis applying appropriate weights to the criteria, it could be concluded from the results that the optimal post mining land use for the Salman south pit is arable farmland and timber production. Following in the ranking order were aquaculture, recreational site (park), shrubs and native forestation and water reservoir. The least preferred option was landfill.

\subsection{Recommendations}

The research approach has given a pragmatic ranking of the suitable alternatives available to the mine in its closure decision of the Salman south pit which is worth implementing. Thus, the Salman south pit is recommended to be converted to useable form for the local mining community who are farmers to continue with their indigenous farming activities and go into cash crop production such as the cultivation of teak and rubber (timber production).

In order to facilitate closure planning for the entire mine, it is recommended that the study be expanded to cover other areas such as the tailings storage facility, water storage facility, processing plant, stockpile areas, haul roads and waste dump.

Other multi-criteria decision analysis techniques such as Elimination EtChoix Traduisant la REalite (ELECTRE) and Technique for Order Preference by Similarity to an Ideal Solution (TOPSIS) could be used for the analysis to compare the results.

\section{Acknowledgements}

The authors are grateful to the management and staff of the Mining, Geology, Safety, Environment, and Community Affairs Departments of Adamus Resources Limited for their support during the research.

\section{References}

Alexander, M. J. (1996). The effectiveness of small-scale irrigated agriculture in the reclamation of mine land soils on the Jos Plateau of Nigeria. Land Degradation \& Development, 7, 77-85.

Bangian, A. H., Ataei, M., Sayadi, A., \& Gholinejad, A. (2011). Fuzzy analytical hierarchy processing to define optimum post mining land use for pit area to clarify reclamation costs, Gospodarka Surowcami Mineralnymi, 27, 145-168.

Bascetin, A. (2007). A decision support system using analytical hierarchy process for the optimal environmental reclamation of an open-pit mine, Environ. Geol., 52(4), 663-672.

Brodie, M. J., Robertson, A. M., \& Gadsby, J. W. (1992). Cost effective closure plan management for metal mines. Retrieved from http://www.robertsongeoconsultants.com/papers/metal_mines.pdf. Accessed April 2012

Cao, X. (2007). Regulating mine land reclamation in developing countries: The case of China. Land-use Policy, $24,472-483$.

Coppin, N. J., \& Box, J. (1999). Sustainable rehabilitation and revegetation: The identification of after-use options for mines and quarries using a land suitability classification involving nature conservation, In A. Warhurst, \& L. Moronha (eds.), Environmental policy in mining: corporate strategy and planning for closure (Chap. 12, pp. 57-75). New York, Lewis Publishers.

De Montis, A., De Toro, P., Droste-Franke, B., Omamm, I., \& Stagl, S. (2000). Criteria for quality assessment of MCDA Methods". Proceedings of the 3rd Biennial Conference of the European Society for Ecological Economics, Vienna, 21-27.

Department for Communities and Local Government. (2009). Multi-criteria analysis: A manual (pp. 12-23). London: Communities and Local Government Publications. Retrieved from https://www.gov.uk/ government/uploads/system/uploads/attachment_data/file/7612/1132618.pdf

European Commission. (2009). Management of tailings and waste rock in mining activities. Reference Document on Best Available Techniques, European Commission, 511 pp. Retrieved from http://eippcb.jrc.ec.europa.eu/reference /BREF/mmr_adopted_0109.pdf 
Heikkinen, P. M., Noras, P., Salminen, R., Mroueh, GTK U.-M., Vahanne, P., ... Komppa, V. (2008). Mine closure handbook (pp. 21-25). Finland: Geological Society of Finland.

Hong, I. B., \& Vogel, D. R. (1991). Data and model management in a generalized MCDM-DSS*. Decision Sciences, 22. Wiley Online Library.

Joerin, F., Theriault, M., \& Musy, A. (2001). Using GIS and outranking multicriteria analysis for land suitability assessment. Int. J. Geogr. Inform. Sci., 15, 153-174.

Johnson, N., de Klerk, Q., Yeo, W., \& Roux, A. (2013). Technical report and mineral resource and reserve update for the Nzema Gold Mine, Ghana, West Africa (Unpublished technical report) (pp. 4-18). Endeavour Mining Corporation, Cayman Islands. Retrieved from https://s21.q4cdn.com/954147562/files/ doc_downloads/technical_report/Ian-Hamilton-technical-report-nzema.pdf

Masoumi, I., \& Rashidinejad, F. (2011). Preference ranking of post-mining land-use through LIMA framework, 9th International Conference on Clean Technologies for the Mining Industry (Cleanmining). Santiago, Chile.

Mougeot, L. J. A. (2002). Breaking new ground: Mining, minerals, and sustainable development: The report of the MMSD Project, Earthscan Publications Ltd, London, 441 pp.

QMC. (2001). Guideline for mine closure planning in Queensland, Queensland Mining Council (QMC), Brisbane, Queensland, 2001 (pp. 4-8). Retrieved from https://www.commdev.org/userfiles/files/ 1356_file_Queensland_20_Mine_20Closure_20Guidelines.pd

Soltanmohammadi, H., Osanloo, M., \& Aghajani Bazzszi, A. (2008). Developing a fifty-attribute framework for mined land suitability analysis using AHP-TOPSIS Approach, Post-Mining, Nancy, France.

Soltanmohammadi, H., Osanloo, M., Rezaei, B., \& Aghajani Bazzazi, A. (2008). Achieving to some outranking relationships between post mining land uses through mined land suitability analysis. International Journal of Environmental Science \& Technology, 5(4), 535-546.

Starke, L. (ed), (2008), Planning for integrated mine closure: Toolkit. International Council on Mining and Metals (ICMM), London, 2008, p. 9. Retrieved from https://www.icmm.com/website/publications/pdfs/ mine-closure/310.pdf

Warhust, A., \& Noronha, L. (2000). Corporate strategy and viable future land use: Planning for closure from the outset of mining, Natural Resources Forum, 24, 153-164.

Working Group. (2006). Mine closure and completion. Leading Practice Sustainable Development Program for the Mining Industry, Australia Government, Ministry of Industry, Tourism and Resources (pp. 5-18). Retrieved from http://www.industry.gov.au/resource/Documents/LPSDP/LPSDP-MineClosure Completion Handbook.pdf

\section{Copyrights}

Copyright for this article is retained by the author(s), with first publication rights granted to the journal.

This is an open-access article distributed under the terms and conditions of the Creative Commons Attribution license (http://creativecommons.org/licenses/by/4.0/). 